\title{
Effects of combined carbohydrate and protein supplementation on athletic performance and recovery of endurance runners $\llbracket a$ double blind, random trial
}

\section{Yiheng Liang}

Beijing Sport University https://orcid.org/0000-0003-3259-2365

\section{Fan Yang}

Beijing Sport University

\section{Yan Chen}

Beijing Sport University

\section{Guoqiang Geng}

Beijing Sport University

\section{Mingyue Lu}

Beijing Sport University

Ruirui Gao

Beijing Sport University

\section{Longyan Yi}

Beijing Sport University

Junqiang Qiu ( $\sim$ qiujq001@sina.com )

Beijing Sport University https://orcid.org/0000-0001-8313-9216

\section{Research article}

Keywords: Endurance Exercise, Sports Beverage, Fatigue and Recovery

Posted Date: March 19th, 2021

DOI: https://doi.org/10.21203/rs.3.rs-330022/v1

License: () (1) This work is licensed under a Creative Commons Attribution 4.0 International License. Read Full License 


\section{Abstract \\ Background}

The aim of this study is to explore the effects of ingesting protein supplementation before endurance exercise.

\section{Methods}

10 recreationally active male runners $\left(\mathrm{VO}_{2 \max }: 53.61 \pm 3.86 \mathrm{ml} / \mathrm{kg} \cdot \mathrm{min}\right)$ completed a run-to-exhaustion test three times. Each test involved 90 minutes of running at $70 \% \mathrm{VO}_{2 \mathrm{max}}$, followed by a time to exhausted test for running at $80 \% \mathrm{VO}_{2 \max }$. All subjects ingested three different, randomly assigned, supplement before the first phase. At the end of the first phase, $\mathrm{CHO}$ (carbohydrate) + $\mathrm{CHO}$; $\mathrm{PRO}$ (protein) + $\mathrm{CHO}$; $\mathrm{CHO}$ + PRO. Both carbohydrate and protein were supplemented at $0.4 \mathrm{~g} \cdot \mathrm{kg}^{-1} \mathrm{BM}^{-1}$. Blood samples were obtained before, immediately after and $24 \mathrm{~h}$ after exercise for alanine aminotransferase (ALT), aspartate aminotransferase (AST), creatine kinase (CK), and myoglobin (MB).

\section{Results}

Three different supplement regimens did not cause a significant difference in exhaustion time ( $\mathrm{CHO}+$ CHO: $432.36 \pm 225.51 \mathrm{~s} ; \mathrm{PRO}+\mathrm{CHO}: 463.82 \pm 227.45 \mathrm{~s} ; \mathrm{CHO}+\mathrm{PRO}: 461.45 \pm 248.5 \mathrm{~s})$. However, ALT and AST in PRO + $\mathrm{CHO}$ were significantly lower than $\mathrm{CHO}+\mathrm{CHO} 24 \mathrm{~h}$ after exercise (ALT: $16.8 \pm 6.31$ VS. 24.39 $\pm 2.54 \mathrm{U} / \mathrm{L} ; \mathrm{AST}: 24.06 \pm 4.77$ VS. $31.51 \pm 7.53 \mathrm{U} / \mathrm{L}, p<0.05)$, and $\mathrm{MB}$ in $\mathrm{PRO}+\mathrm{CHO}$ and $\mathrm{CHO}+\mathrm{PRO}$ were significantly lower than $\mathrm{CHO}+\mathrm{CHO} 24 \mathrm{~h}$ after exercise $(40.71 \pm 15.16 ; 38.12 \pm 14.32 ; 64.32 \pm 28.86 \mathrm{ng} / \mathrm{mL}$, respectively, $p<0.05)$. Compared to $\mathrm{CHO}+\mathrm{CHO}, \mathrm{CK}$ in $\mathrm{PRO}+\mathrm{CHO}$ increased less $24 \mathrm{~h}$ after exercise $(404.22 \pm 75.31$ VS. $642.33 \pm 68.57 \mathrm{U} / \mathrm{L}, p<0.05)$.

\section{Conclusion}

Although combined carbohydrate and protein supplementation did not prolong exhaustion time, it can effectively relieve muscle damage, and it is better to supplement PRO before exercise.

\section{Introduction}

As a direct energy supply substance in exercise, the content of endogenous carbohydrate is closely tied to endurance performance, increasing the amount of endogenous carbohydrate that can enable endurance athletes to have sufficient energy supply during the competition $(1,2)$.

Recently, studies have suggested that compared to carbohydrate supplementation alone, adding protein in traditional carbohydrate supplementation can improve endurance performance better(3-5). However, 
the physiological mechanism of improving endurance performance is unclear. Studies found that combined supplementation of carbohydrate and protein can stimulate higher insulin response $(6,7)$, and glucose transport is primarily stimulated by insulin and muscle contraction(8). Therefore, some arguments suggest that additional protein increases insulin, which improves muscle glycogen synthesis for endurance performance $(3,4,9)$. Similar research(4) have also found that muscle injury biomarkers, such as creatine kinase, myoglobin, appear to be lower, thereby suggesting that the intake of additional protein can reduce muscle damage and improve endurance performance. However, in those researches that found carbohydrate plus protein can improve endurance performance, there is a problem of unequal calories, which makes it difficult to explain whether this benefit comes from protein or other factors.(3-5, $10,11)$.

For strength training, ingesting $20-40 \mathrm{~g}$ of high-quality protein immediately after the end of exercise can increase muscle synthesis rate and reduce muscle damage $(1,12,13)$. However, for endurance exercise, few studies clearly indicate the timing to supplement protein for endurance exercise. In studies that explored the effect of carbohydrate plus protein supplementation on endurance performance, the timing of supplementation is mostly during or after exercise, but few studies explored the effects of ingesting protein supplementation before endurance exercise. Endurance exercise can cause significant muscle damage due to its long distance and prolong exercise characteristics(14-17). Therefore, the main purpose of this study is to explore the effect of carbohydrate plus protein supplementation on endurance exercise and muscle damage at different timings in the case of equal calories.

\section{Materials And Methods \\ Participants}

This experiment recruited 11 recreationally active male runners from China Athletics College of Beijing Sports University, who all train at least 3 times a week (over 6 hours). Participants were forbidden from taking other sports supplements during the experiment and performance heavy exercise outside the experiment. During the experiment, one subject could not complete subsequent experiments due to injury. Therefore, a total of 10 subjects completed the entire experimental procedure. Subjects' characteristics are present in Table 1. Before the experiment, subjects were informed of the experimental procedures and possible risks.

All procedures of the experiments were approved by the Institutional Review Board of Beijing Sport University (BSU IRB).

Table 1

characteristic of subjects

\begin{tabular}{|lllll|}
\hline Number & Age & Height $(\mathrm{cm})$ & Weight $(\mathrm{kg})$ & $\mathrm{VO}_{2 \max }(\mathrm{ml} / \mathrm{kg} \cdot \mathrm{min})$ \\
\hline 10 & $21 \pm 2$ & $175.1 \pm 4.2$ & $62.8 \pm 5.3$ & $53.61 \pm 3.86$ \\
\hline
\end{tabular}




\section{Preliminary measurements}

The subjects went to the laboratory for the baseline test. The experiment requires that the subjects do not perform heavy exercise for the first three days of the baseline test and maintain a normal diet and rest time to obtain a more accurate baseline value. The baseline test included venous blood collection, morning urine collection and the maximum oxygen uptake $\left(\mathrm{VO}_{2 \max }\right)$ was tested. $\mathrm{VO}_{2 \max }$ was performed on the running platform ( $\mathrm{h} / \mathrm{p} /$ cosmos Mercury4.0, Germany) by the gas metabolism test system (COSMEDk4b2, Italy).

\section{Experimental design}

The study used a randomized crossover double-blind design with self-control. Participants performed three running to exhaustion tests and were assigned different supplements in a random order in each running test. There was a seven-day washout period between each test.

Thirty minutes before the test, the subjects ingested the assigned pre-running supplement. Before starting the test, a venous blood collection was performed and muscle soreness was recorded. After completing the first phase of the run-to-exhaustion test, the subjects ingested mid-running supplement, then completed the second phase of the run-to-exhaustion test. Immediately after the run-to-exhaustion test, the subjects' venous blood was collected, and subjective fatigue was recorded by muscle soreness. The morning urine was collected on the second day of the exercise test, and 24 hours after the end of the test, venous blood collection and muscle soreness recording were performed (Fig. 1).

\section{Experimental Protocol}

The run-to-exhaustion tests were performed on an indoor running platform ( $\mathrm{h} / \mathrm{p} / \mathrm{cosmos}$ Mercury4.0, Germany). The run-to-exhaustion test was divided into two phases with no time interval between the two phases. In the first phase, the subjects ran for 1 hour at $70 \% \mathrm{VO}_{2 \max }$ on the running platform with a slope of $0^{\circ}$. After completing the 1 -hour quantitative load running, the subjects ran to exhaustion at $80 \% \mathrm{VO}_{2} \max$ with a slope of $0^{\circ}$ in the second phase. In the second phase, the experimenters continuously encourage to subjects to make them as unaffected as possible in achieving true exhaustion. (Fig 2)

The subjects were supplemented with three different supplement regimens in random order on three running tests. The three different supplement regimens were 1 ingest carbohydrate at 30 minutes before the first phase and the end of the first phase $(\mathrm{CHO}+\mathrm{CHO}) ; 2$ ingest protein at 30 minutes before the first phase and ingest carbohydrate at the end of the first phase (PRO $+\mathrm{CHO}) ; 3$ ingest carbohydrate at 30 minutes before the first phase and ingest protein at the end of the first phase ( $\mathrm{CHO}+\mathrm{PRO})(\mathrm{Fig} 2)$

\section{Solution composition}

Except for the supplement provided by the experiment, the subjects did not consume any other nutritional supplements. The three supplement regimens have the same caloric intake, and the timing of 
supplementation was 30 minutes before the first phase and at the end of the first phase. The protein in the supplement is whey protein isolate (Whey protein isolate LacprodanRDI-9224, Arla Foods Ingredients $\mathrm{P} / \mathrm{S}$ ) and each supplement dose was $0.4 \mathrm{~g} \cdot \mathrm{kg}^{-1} \cdot \mathrm{BM}^{-1}$. The carbohydrate was maltodextrin (Xiwang Group $\mathbb{Z}$ China), and each supplement dose was $0.4 \mathrm{~g} \mathrm{~kg}^{-1} \cdot \mathrm{BM}^{-1}$. At the same time, the subjects were supplemented with carbohydrate at $1.2 \mathrm{~g} \mathrm{~kg}^{-1} \cdot \mathrm{BM}^{-1}$ during the first phase, which was ingested every 10 minutes in the form of a liquid. All supplements were formulated with water at a concentration of $20 \%$ and contained artificially sweetened solution (no calorie) to make same taste. (Table 1)

The experiment conducted dietary intervention on the subjects. One day before the running test, on the day of the test and on the day after the end of the test, the subjects were required to adhere to the experimental dietary recommendations and record their daily calorie intake. The energy intake proportion of the three nutrients is $50 \%$ carbohydrates, $20 \%$ proteins, and $30 \%$ fats. Finally, the daily energy intake of the subjects was approximately $2561 \pm 357.3 \mathrm{kcal}$. During the three-day diet intervention of each test, the experiment required subjects' food intake of the previous test to be consistent with that of the previous test in order to reduce the effect of diet on the experimental results.

Table 2 Ingredients of supplements. Pre, 30 minutes before the first phase; Mid, the end of the first phase; During $\mathrm{CHO}$, the carbohydrate ingested during the first phase

\begin{tabular}{|llll|}
\hline & Pre or Mid protein & Pre or Mid carbohydrate & During carbohydrate \\
\hline Weight $(\mathrm{g})$ & $25.12 \pm 2.11$ & $25.12 \pm 2.11$ & $5.37 \pm 6.33$ \\
\hline Volume $(\mathrm{ml})$ & $125.62 \pm 10.56$ & $125.62 \pm 10.56$ & $376.86 \pm 31.67$ \\
\hline
\end{tabular}

\section{Blood and urine analysis}

Subjects performed a baseline venous blood collection before the start of the formal experiment, and in the next three tests, the venous blood was obtained before each test, immediately after the test, and 24 hours after the test. Blood samples were collected into a $5 \mathrm{ml}$ gel serum tube (Vacuette, Frickenhausen, Germany). Alanine aminotransferase (ALT), aspartate aminotransferase (AST), and creatine kinase (CK) were determined with a fully automatic biochemical analyzer (Beckman DXI 800, Beckman Coulter, Fullerton, $C A$, USA). Myoglobin (MB), insulin, testosterone ( $T$ ), and cortisol (C) were measured with a fully automatic immunoanalyzer. (Beckman DXC 800, Beckman Coulter, Fullerton, CA, USA).

Before the start of the formal experiment, the subjects collected a morning urine as a baseline value. For three days before and after the baseline morning urine collection, heavy exercise was forbidden, and energy intake was based on the experimental recommended diet. In the three subsequent tests, morning urine was collected the next day after the test. 3-methylhistidine (3-MH) in urine was determined with ELISA (BOS-47007, BOSK, China).

\section{Statistical analysis}


SPSS 20.0 was used to analyze all the data in the experiment, and the experimental data were expressed as mean \pm standard deviation. All data were tested by Shapiro-Wilk. Using repeated measurements MANOVA to perform statistical analysis on AST, ALT, insulin, CK, T, C, and muscle soreness (VAS) to compare these indicators on different timing (before the test, immediately after the test, 24 hours after the test) and the differences between the three groups of supplement regimens. Exhaustion time and 3methylhistidine (3-MH) were performed through a one-way analysis of variance. When $\mathrm{p} \otimes 0.05$, it is defined as a significant difference in data.

\section{Results}

\section{Endurance performance}

It can be seen from Fig. 3a that there is no significant difference in the time of run-to-exhaustion after one hour of quantitative load running between the three groups, and the exhaustion time of the three groups is about 400 seconds.

\section{Blood and urine analyses}

Figure 4a shows that the insulin concentration of the three groups before exercise was significantly higher than the baseline value. Immediately after exercise, the insulin concentration of the three groups showed a downward trend, and the PRO + $\mathrm{CHO}$ was still significantly higher than the baseline value. However, there was no significant difference in insulin concentration before and immediately after exercise between the three groups.

Compared with before exercise, the ALT and AST values of the three groups increased immediately after exercise. ALT and AST in PRO + $\mathrm{CHO}$ group were significantly lower than $\mathrm{CHO}+\mathrm{CHO}$ group immediately after exercise (ALT: $22.75 \pm 6.22$ vs $31.74 \pm 4.79 \mathrm{U} / \mathrm{L} ; \mathrm{AST}: 23.14 \pm 3.3$ vs $29.39 \pm 5.16 \mathrm{U} / \mathrm{L}, p \otimes 0.05)$ ). At 24 hours after exercise, AST and ALT in PRO + $\mathrm{CHO}$ group were also significantly lower than in $\mathrm{CHO}+\mathrm{CHO}$ group(ALT: $16.8 \pm 6.31$ vs $24.39 \pm 2.54 \mathrm{U} / \mathrm{L} ; \mathrm{AST}: 24.06 \pm 4.77$ vs $31.51 \pm 7.53 \mathrm{U} / \mathrm{L}, p \otimes 0.05)$ (Fig. $4 \mathrm{~b}, \mathrm{c})$.

The CK value of the three groups showed an upward trend after exercise. In the three test points, only 24 hours after exercise, the $\mathrm{CK}$ value of $\mathrm{PRO}+\mathrm{CHO}$ was significantly lower than $\mathrm{CHO}+\mathrm{CHO}(404.22 \pm 75.31$ vs $642.33 \pm 68.57 \mathrm{U} / \mathrm{L}, p \otimes 0.05$ ) (Fig. $4 \mathrm{~d}$ ). Compared with before exercise, the MB values of the three groups increased immediately after exercise, but there was no significant difference between three groups. At 24 hours after exercise, the $\mathrm{MB}$ values of $\mathrm{PRO}+\mathrm{CHO}$ and $\mathrm{CHO}+\mathrm{PRO}$ were significantly lower than $\mathrm{CHO}+\mathrm{CHO}$ (PRO + CHO: $40.71 \pm 15.16 \mathrm{ng} / \mathrm{mL} ; \mathrm{CHO}+\mathrm{PRO}: 38.12 \pm 14.32 \mathrm{ng} / \mathrm{mL} ; \mathrm{CHO}+\mathrm{CHO}: 64.32$ $\pm 28.86 \mathrm{ng} / \mathrm{mL}, p \otimes 0.05$ ) (Fig. 4e).

At immediately after exercise, the $\mathrm{T}$ and $\mathrm{C}$ values were significantly higher than before the exercise, and 24 hours after exercise, the $T$ and $C$ values decreased. However, there were no significant differences in $T$ and $C$ values in different treatments. 
In different treatments, 3-MH was significantly higher than the baseline value $24 \mathrm{~h}$ after exercise (Base line: $122.00 \pm 14.64 ; \mathrm{PRO}+\mathrm{CHO}: 142.10 \pm 15.81 ; \mathrm{CHO}+\mathrm{PRO}: 128.98 \pm 8.8 ; \mathrm{CHO}+\mathrm{CHO}: 124.65 \pm 15.45$. $p \Downarrow 0.05)$, and the $3-\mathrm{MH}$ value of $\mathrm{PRO}+\mathrm{CHO}, \mathrm{CHO}+\mathrm{PRO}$ was significantly lower than $\mathrm{CHO}+\mathrm{CHO}(p \otimes 0.05)$. (Fig. 3b)

In Fig. 3c, the VAS values of three groups at immediately after exercise and $24 \mathrm{~h}$ after exercise were significantly higher than before exercise $(p<0.05)$. There was no significant difference in VAS values between the three groups at immediately after exercise, but $24 \mathrm{~h}$ after exercise, the VAS of PRO $+\mathrm{CHO}$ and $\mathrm{CHO}+\mathrm{PRO}$ was significantly lower than $\mathrm{CHO}+\mathrm{CHO}(p<0.05)$.

\section{Discussion}

\section{Endurance performance}

Compared with consuming carbohydrate alone, ingesting additional protein groups did not significantly improve endurance performance. The three groups had the same caloric intake, which may be the reason why we did not find improved performance like previous studies did. The other reason may be related to exercise intensity. In this experiment, the subjects exercised to exhaustion at $80 \% \mathrm{VO}_{2 \max }$. Ferguson et al. (11) suggests that compared to carbohydrate supplementation alone, carbohydrate plus protein can improve aerobic endurance during exercise intensity near the ventilatory threshold.

In addition, there was no significant difference in insulin concentration between the three groups before and immediately after exercise. In this experiment, the supplement of carbohydrate and protein in this experiment was performed separately. However, those experiments that found the combination of carbohydrate and protein supplementation can enhance the insulin response, carbohydrate and protein are ingested at the same time $(7,18)$. This may be the reason why we did not find a difference between the three groups of insulin. In the study by McCleave et al.(5), although the exhaustion time of carbohydrate plus protein was longer than carbohydrate supplement, and the blood glucose concentration of carbohydrate plus protein was significantly lower than carbohydrate supplement, they also found no difference in insulin concentration. In Ang et al.'s(19) experiments on subjects with type 2 diabetes, they found that although insulin concentrations increased, glucose uptake rates did not change. Therefore, changes in insulin concentration cannot effectively explain changes in glycogen synthesis in the body. Thus, the claim that endurance performance improves because of extra insulin production caused by carbohydrate plus protein still needs further proof.

\section{Muscle injury and fatigue recovery}

Endurance exercise results in increased levels of cytokines and changes in muscle, heart, liver, and kidneys (20-22). AST and ALT are usually analyzed in serum to assess and monitor liver damage and possible liver virus infections. ALT is mainly found in the liver, but also found in lower amounts in the kidney, heart, muscle, and pancreas. AST is present in the liver, but a considerable amount of it is also present in other tissues including muscle (23). Therefore, analyzing AST and ALT in blood can observe 
the muscle damage and liver damage caused by exercise. In this experiment, ALT and AST values of the $\mathrm{PRO}+\mathrm{CHO}$ were significantly lower than $\mathrm{CHO}+\mathrm{CHO}$ immediately after exercise and after 24 hours of exercise. This might be explained by the fact that extra protein provides more amino acids for the muscle, which reduce muscle cell damage caused by repeated muscle contraction during long-distance running. In addition, protein supplementation may affect energy metabolism during exercise, so that aerobic energy supply accounts for a greater proportion of exercise and reduces liver stress during exercise, thereby reducing the damage to liver cells during hypoxia. On the other hand, the ALT and AST values of the $\mathrm{CHO}+\mathrm{PRO}$ were also lower than $\mathrm{CHO}+\mathrm{CHO}$, but there was no statistical difference. It seems that protein supplementation is a better way than carbohydrate supplementation alone to reduce muscle damage caused by running and accelerate recovery after exercise, and protein supplementation before exercise has a better protective effect on the damage caused by long-term running.

Excessive exercise can cause delayed muscle soreness, decreased strength, and increased muscle protein levels in the blood, including CK, lactate dehydrogenase, and MB(23). Therefore, MB, CK, lactate dehydrogenase and other indicators are commonly used as serum markers for muscle injury to observe muscle status (24). After sarcomere damage caused by exercise, the damaged skeletal muscle cells will increase $\mathrm{CK}$ in the serum, and the CK activity in the serum will increase significantly 24 hours after exercise, then gradually return(25). Although protein is not the main energy source in exercise, it still contributes to total energy consumption during prolonged aerobic or endurance exercise $(12,26)$. One hypothesis in the previous study is that the reduction of free amino acid pool in muscle tissue may cause muscle protein breakdown(27). In this experiment, MB in ingested protein groups is significantly lower than $\mathrm{CHO}+\mathrm{CHO}$ at $24 \mathrm{~h}$ after exercise. In addition, although $\mathrm{CK}$ in $\mathrm{PRO}+\mathrm{CHO}$ and $\mathrm{CHO}+\mathrm{PRO}$ is lower than $\mathrm{CHO}+\mathrm{CHO}$ at $24 \mathrm{~h}$ after exercise, only $\mathrm{PRO}+\mathrm{CHO}$ was significantly lower than $\mathrm{CHO}+\mathrm{CHO}$. The reason that protein supplementation before exercise is more effective might be because the protein intake in advance increases the concentration of amino acids in the blood, thereby reducing muscle damage and speeding up recovery after exercise. Furthermore, in the two groups supplemented with protein, the VAS at $24 \mathrm{~h}$ after exercise was lower than $\mathrm{CHO}+\mathrm{CHO}$. This may be partly because the supplemented protein increased the recovery time of skeletal muscle. On the other hand, intake of protein may increase central neuronal neurotransmitters such as serotonin(28), thereby reducing VAS levels.

This experiment also tested the indicators of muscle injury in urine and found that the level of 3-MH in urine in the three groups after exercise increased significantly compared with before exercise. After exercise, the 3-MH level in $\mathrm{PRO}+\mathrm{CHO}$ and $\mathrm{CHO}+\mathrm{PRO}$ was significantly lower than $\mathrm{CHO}+\mathrm{CHO}$, but there was no significant difference between the $\mathrm{PRO}+\mathrm{CHO}$ group and the $\mathrm{CHO}+\mathrm{PRO}$ group. 3-MH can reflect the degradation of skeletal muscle protein due to muscle contraction during exercise(29). The two groups supplemented with protein in this experiment were significantly lower than the $\mathrm{CHO}+\mathrm{CHO}$. A possible explanation for this is that the protein supplement provided more amino acids during exercise than the carbohydrate-only group, thereby resulting in attenuation of increases in 3-MH and speeded up recovery after exercise. 
The experimental data showed that there was no significant difference in $\mathrm{T}$ and $\mathrm{C}$ in the three groups at different time points. As the most active androgen in the body, testosterone can stimulate tissues to take up amino acids and promote protein synthesis $(30,31)$. Overall, testosterone can promote anabolic metabolism in the body. Studies by Beelen et al. (32)showed that although continuous endurance exercise stimulates muscle protein synthesis, protein supplementation during continuous endurance exercise does not increase the rate of muscle protein synthesis. Our experiment did not measure protein synthesis indicators, but the experimental insulin results also did not appear significantly different among the three groups. Another reason that the testosterone did not appear to be different may be due to insufficient doses of protein supplements, especially leucine. Pasiakos et al. (33) observes that the measurement of leucine will significantly affect muscle protein synthesis. Although there is no significant difference in $\mathrm{T}$ and $\mathrm{C}$ between the three groups in this experiment, it can be found from the above that the muscle injury indicator of the two groups supplemented with protein before or during exercise is significantly lower than the carbohydrate-only group. Protein supplementation increases the concentration of amino acids in the body, thereby reducing muscle damage caused by endurance exercise and speeding up recovery after exercise. However, the protein supplement dosage may not significantly change the muscle protein synthesis. Therefore, the data showed that the muscle damage indicator of the two groups supplemented with protein was lower than the carbohydrate-only group, but there was no difference in $\mathrm{T}$ and $\mathrm{C}$ between the three groups.

\section{Conclusion}

In the case of sufficient carbohydrate intake, protein intake before or during exercise cannot extend the time that runners sprint to exhaustion in endurance exercise. For endurance exercise, compared with carbohydrate supplementation alone, the combined supplement of carbohydrates and protein can effectively reduce muscle damage caused by endurance exercise and promote fatigue recovery after exercise. In addition, compared with protein supplementation during exercise, protein supplementation before exercise can better improve muscle damage caused by endurance exercise.

\section{Abbreviations}

CHO: carbohydrate; PRO: protein; ALT: alanine aminotransferase; AST: aspartate aminotransferase; CK: creatine kinase; MB: myoglobin; T: testosterone; C: cortisol; 3-MH: 3-methylhistidine.

\section{Declarations}

\section{ACKNOWLEDGMENTS}

We would like to sincerely thank to all the participants for participating in this study and the College of Sport Science School and Institute of Sport and Health Sciences of Beijing Sport University for the data collection. 
The datasets generated and/or analyzed as part of the current study are not publicly available due to confidentiality agreements with subjects. However, they can be made available solely for the purpose of review and not for the purpose of publication from the corresponding author upon reasonable request.

\section{ETHICS STATEMENT}

The research proposal was approved by the Institutional Review Board of Beijing Sport University (BSU IRB) and all participants gave written informed consent prior to study participation(2019110H).

\section{AUTHOR CONTRIBUTIONS}

YL was responsible for data collection, data interpretation, writing and revision of the manuscript, under the direction and assistance of JQ and LY who assisted with each step and completion of the manuscript. $\mathrm{FY}, \mathrm{YC}, \mathrm{GG}$ and $\mathrm{ML}$ assisted in the exercise programs and in the data collection. RG assisted in the revision of the manuscript.

\section{FUNDING}

Funding was provided by the National Key R\&D Program of China (2018YFC2000600).

\section{CONSENT FOR PUBLICATION for publication}

Not applicable, no individual person's data was presented.

\section{COMPETING INTERESTS}

The authors declare that they have no competing interests.

\section{AUTHOR DETAILS}

${ }^{1}$ Department of Exercise Biochemistry, Exercise Science School, Beijing Sport University, No. 48 Xinxi Road, Haidian District, Beijing, China. ${ }^{2}$ Institute of Sport and Health Science, Beijing Sport University, Beijing, No. 48 Xinxi Road, Haidian District, Beijing, China.

\section{References}

1. Kerksick CM, Arent S, Schoenfeld BJ, Stout JR, Campbell B, Wilborn CD, et al. International society of sports nutrition position stand: nutrient timing. 2017;14(1):33.

2. Romijn JA, Coyle EF, Sidossis LS, Gastaldelli A, Horowitz JF, Endert E, et al. Regulation of endogenous fat and carbohydrate metabolism in relation to exercise intensity and duration. Am J Physiol. 1993;265(3 Pt 1):E380-E91.

3. Ivy JL, Res PT, Sprague RC, Widzer MO. Effect of a carbohydrate-protein supplement on endurance performance during exercise of varying intensity. Int J Sport Nutr Exerc Metab. 2003;13(3):382-95. 
4. Saunders MJ, Kane MD, Todd MK. Effects of a carbohydrate-protein beverage on cycling endurance and muscle damage. Med Sci Sports Exerc. 2004;36(7):1233-8.

5. McCleave EL, Ferguson-Stegall L, Ding Z, Doerner PG, 3rd, Wang B, Kammer LM, et al. A low carbohydrate-protein supplement improves endurance performance in female athletes. J Strength Cond Res. 2011;25(4):879-88.

6. Manders RJ, Koopman R, Sluijsmans WE, van den Berg R, Verbeek K, Saris WH, et al. Co-ingestion of a protein hydrolysate with or without additional leucine effectively reduces postprandial blood glucose excursions in Type 2 diabetic men. J Nutr. 2006;136(5):1294-9.

7. Zawadzki KM, Yaspelkis BB, 3rd, Ivy JL. Carbohydrate-protein complex increases the rate of muscle glycogen storage after exercise. J Appl Physiol (1985). 1992;72(5):1854-9.

8. Goodyear LJ, Hirshman MF, Horton ES. Exercise-induced translocation of skeletal muscle glucose transporters. Am J Physiol. 1991;261(6 Pt 1):E795-E9.

9. Ferguson-Stegall L, McCleave EL, Ding Z, Doerner PG, 3rd, Wang B, Liao YH, et al. Postexercise carbohydrate-protein supplementation improves subsequent exercise performance and intracellular signaling for protein synthesis. J Strength Cond Res. 2011;25(5):1210-24.

10. Saunders MJ, Luden ND, Herrick JE. Consumption of an oral carbohydrate-protein gel improves cycling endurance and prevents postexercise muscle damage. J Strength Cond Res. 2007;21(3):67884.

11. Ferguson-Stegall L, McCleave EL, Ding Z, Kammer LM, Wang B, Doerner PG, et al. The effect of a low carbohydrate beverage with added protein on cycling endurance performance in trained athletes. $J$ Strength Cond Res. 2010;24(10):2577-86.

12. Kreider RB, Campbell B. Protein for exercise and recovery. Phys Sportsmed. 2009;37(2):13-21.

13. Campbell B, Kreider RB, Ziegenfuss T, La Bounty P, Roberts M, Burke D, et al. International Society of Sports Nutrition position stand: protein and exercise. J Int Soc Sports Nutr. 2007;4:8.

14. Lynn A, Garner S, Nelson N, Simper TN, Hall AC, Ranchordas MK. Effect of bilberry juice on indices of muscle damage and inflammation in runners completing a half-marathon: a randomised, placebocontrolled trial. J Int Soc Sports Nutr. 2018;15:22.

15. Bell PG, Walshe IH, Davison GW, Stevenson E, Howatson G. Montmorency cherries reduce the oxidative stress and inflammatory responses to repeated days high-intensity stochastic cycling. Nutrients. 2014;6(2):829-43.

16. Lippi G, Schena F, Salvagno GL, Montagnana M, Gelati M, Tarperi C, et al. Acute variation of biochemical markers of muscle damage following a $21-\mathrm{km}$, half-marathon run. Scand J Clin Lab Invest. 2008;68(7):667-72.

17. Nie J, Tong TK, George K, Fu FH, Lin H, Shi Q. Resting and post-exercise serum biomarkers of cardiac and skeletal muscle damage in adolescent runners. Scandinavian journal of medicine \& science in sports. 2011;21(5):625-9.

18. van Loon LJ, Saris WH, Verhagen $\mathrm{H}$, Wagenmakers AJ. Plasma insulin responses after ingestion of different amino acid or protein mixtures with carbohydrate. Am J Clin Nutr. 2000;72(1):96-105. 
19. Ang M, Muller AS, Wagenlehner F, Pilatz A, Linn T. Combining protein and carbohydrate increases postprandial insulin levels but does not improve glucose response in patients with type 2 diabetes. Metabolism. 2012;61(12):1696-702.

20. Fallon KE, Sivyer G, Sivyer K, Dare A. The biochemistry of runners in a $1600 \mathrm{~km}$ ultramarathon. $\mathrm{Br} \mathrm{J}$ Sports Med. 1999;33(4):264-9.

21. Clarkson PM, Hubal MJ. Exercise-induced muscle damage in humans. Am J Phys Med Rehabil. 2002;81(11 Suppl):S52-S69.

22. Kratz A, Lewandrowski KB, Siegel AJ, Chun KY, Flood JG, Van Cott EM, et al. Effect of marathon running on hematologic and biochemical laboratory parameters, including cardiac markers. Am J Clin Pathol. 2002;118(6):856-63.

23. Banfi G, Colombini A, Lombardi G, Lubkowska A. Metabolic markers in sports medicine. Adv Clin Chem. 2012;56:1-54.

24. Brancaccio P, Lippi G, Maffulli N. Biochemical markers of muscular damage. Clin Chem Lab Med. 2010;48(6):757-67.

25. Brancaccio P, Maffulli N, Limongelli FM. Creatine kinase monitoring in sport medicine. Br Med Bull. 2007;81-82:209-30.

26. Carli G, Bonifazi M, Lodi L, Lupo C, Martelli G, Viti A. Changes in the exercise-induced hormone response to branched chain amino acid administration. Eur J Appl Physiol Occup Physiol. 1992;64(3):272-7.

27. Tipton KD, Wolfe RRJAPS. Exercise-induced changes in protein metabolism. 1998;162.

28. Bloxam DL, Tricklebank MD, Patel AJ, Curzon G. Effects of albumin, amino acids, and clofibrate on the uptake of tryptophan by the rat brain. J Neurochem. 1980;34(1):43-9.

29. Hickson JF, Jr., Hinkelmann K. Exercise and protein intake effects on urinary 3-methylhistidine excretion. Am J Clin Nutr. 1985;41(2):246-53.

30. Fink J, Schoenfeld BJ, Nakazato K. The role of hormones in muscle hypertrophy. Phys Sportsmed. 2018;46(1):129-34.

31. Herbst KL, Bhasin S. Testosterone action on skeletal muscle. Curr Opin Clin Nutr Metab Care. 2004;7(3):271-7.

32. Beelen M, Zorenc A, Pennings B, Senden JM, Kuipers H, van Loon LJ. Impact of protein coingestion on muscle protein synthesis during continuous endurance type exercise. Am J Physiol Endocrinol Metab. 2011;300(6):E945-54.

33. Pasiakos SM, McClung HL, McClung JP, Margolis LM, Andersen NE, Cloutier GJ, et al. Leucineenriched essential amino acid supplementation during moderate steady state exercise enhances postexercise muscle protein synthesis. Am J Clin Nutr. 2011;94(3):809-18.

\section{Figures}




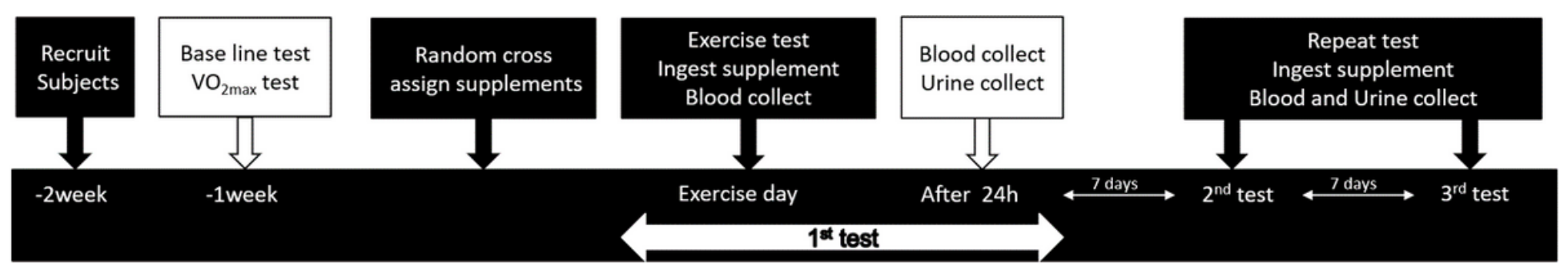

Figure 1

Experimental design. Obtained venous blood before the test, immediately after the test, and 24 hours after the test, and collect morning urine after the test 24 hours.

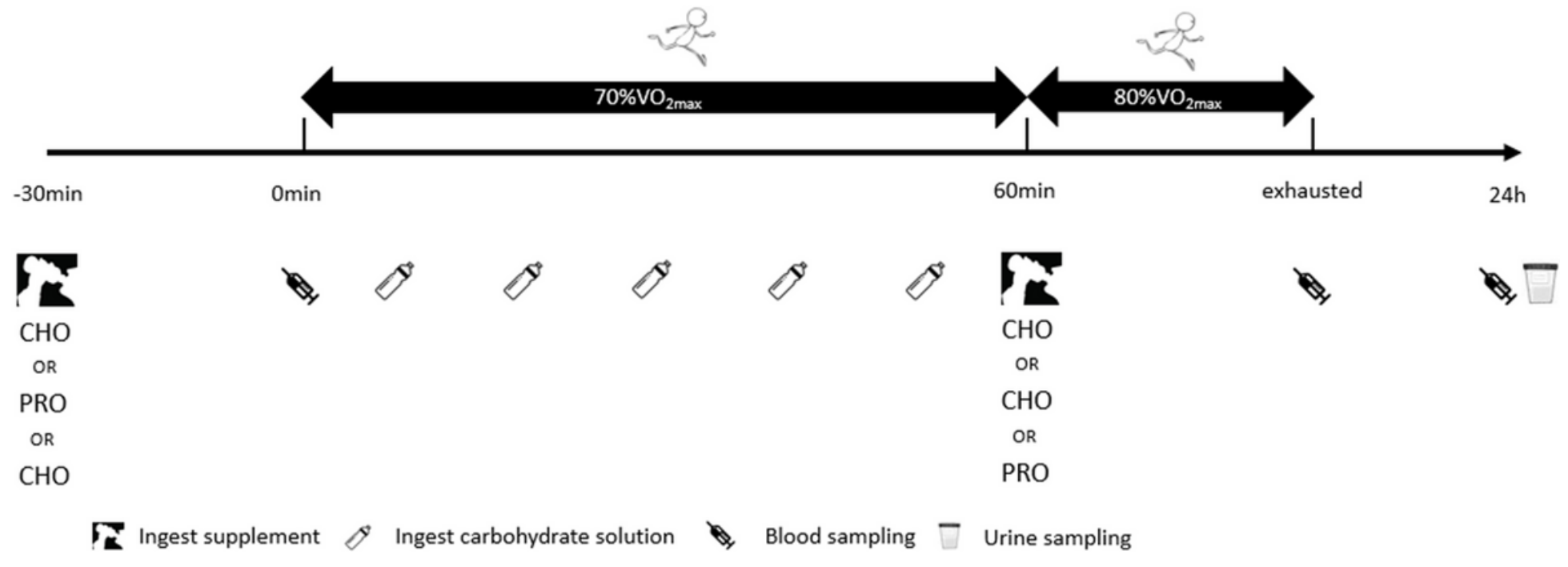

Figure 2

Representation of the study protocol. The subjects took three different supplements randomly in three tests.

a

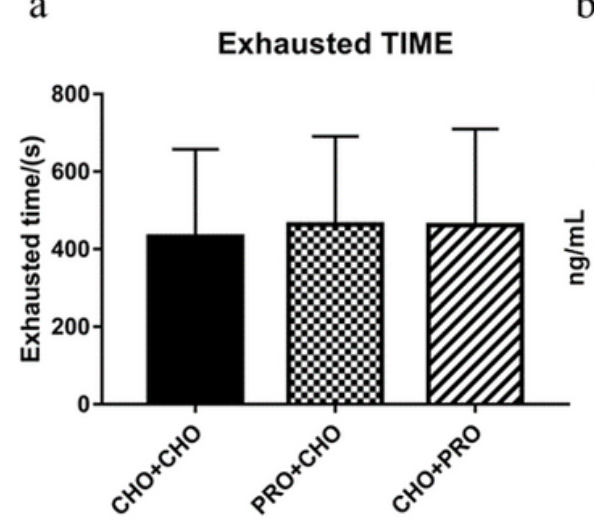

b

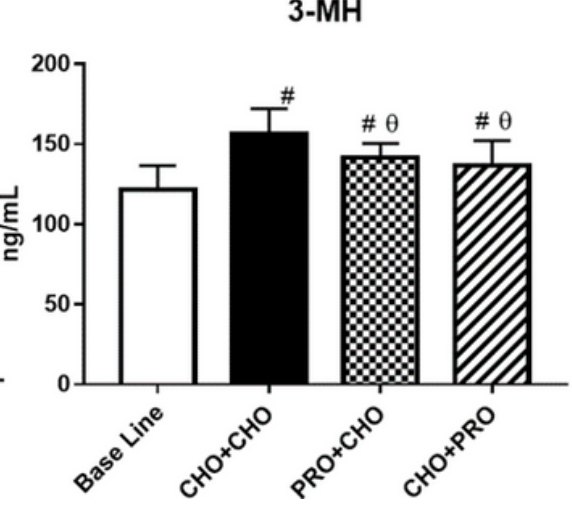

$\mathrm{c}$

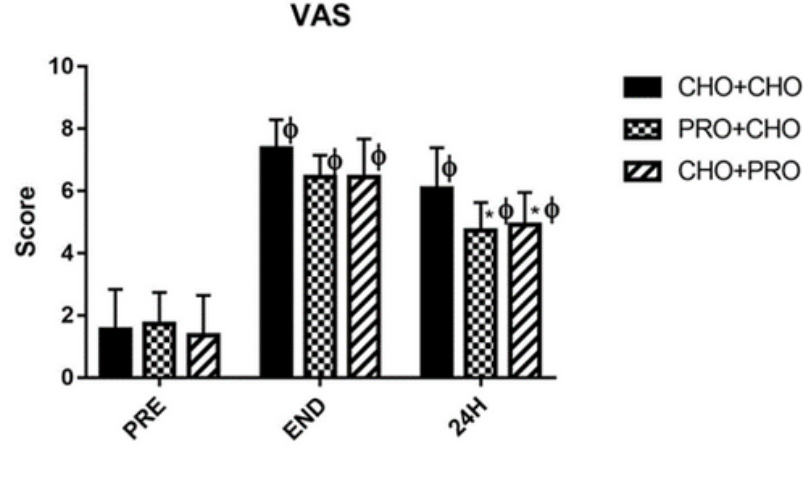

Figure 3

Exhaustion time, 3-MH and VAS of different group. a. Exhaustion time is after one hour of quantitative load running, subjects ran to exhaustion at $80 \%$ VO2max. b. \# indicates a significant difference from the

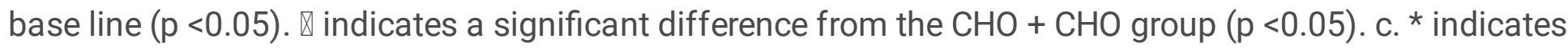


a significant difference compared with $\mathrm{CHO}+\mathrm{CHO}$ at after exercise $24 \mathrm{~h}(\mathrm{p}<0.05) . \varphi$ indicates a significant difference compared with the value of self-group at before exercise $(p<0.05)$.

a

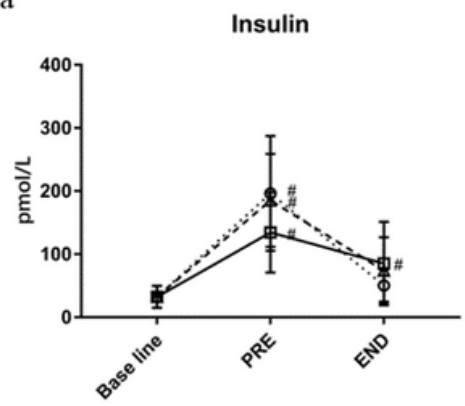

d

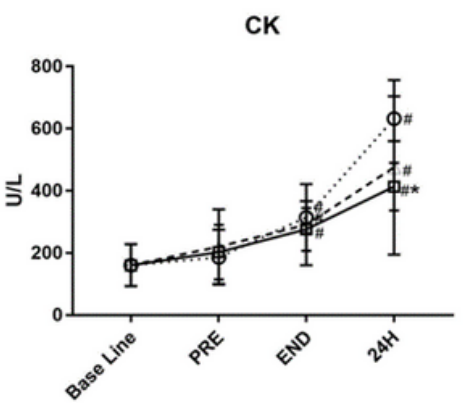

b

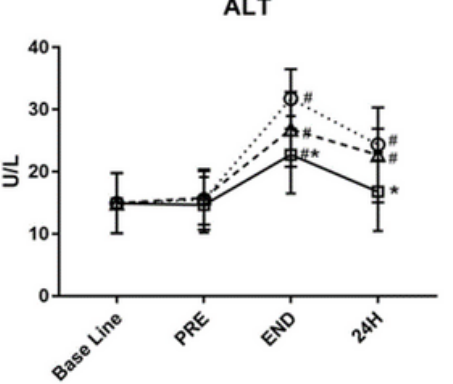

f c

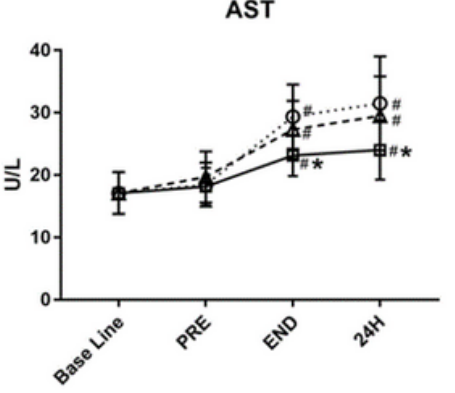

g e

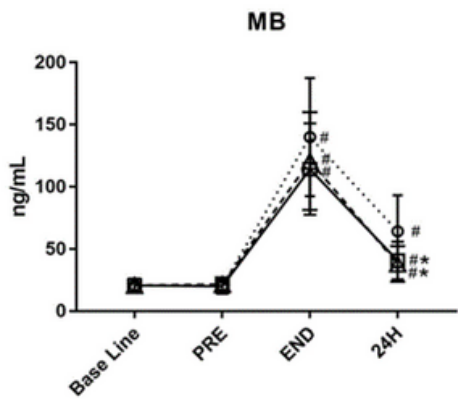

f

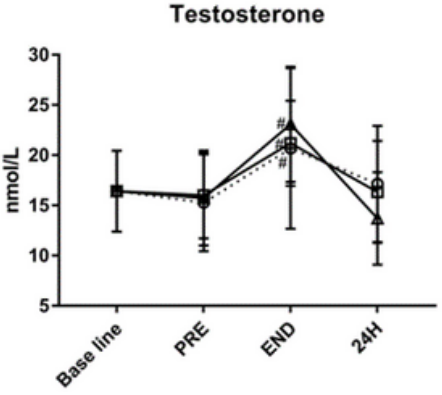

- $2 \mathrm{CHO}+\mathrm{CHO}$

\& $\mathrm{PRO}+\mathrm{CHO}$

$-A \cdot C H O+P R O$

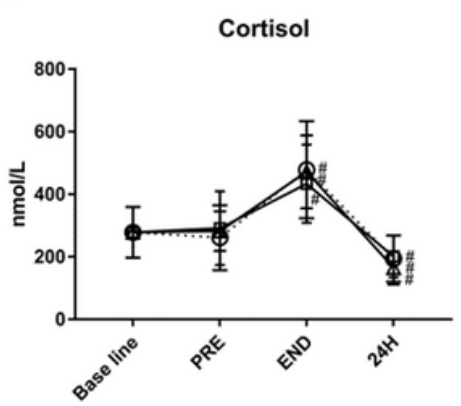

Figure 4

Biochemical indicators in the blood. Before the exercise (PRE). Immediately after exercise (END). 24 hours after exercise (24h). * indicates a significant difference compared with $\mathrm{CHO}+\mathrm{CHO}(\mathrm{p} \otimes 0.05)$. \# indicates a significant difference compared with before exercise ( $p \llbracket 0.05)$. 